PENENTUAN NASABAH PENERIMA REWARD PRODUK GOLD DENGAN METODE SIMPLE ADDITIVE WEIGHTING (SAW) STUDI KASUS : PT. PINJAM INDONESIA

Riki Ruli A. Siregar; Faizal Fachrurrozi

IMPLEMENTASI METODE BACKWARD CHAINING PADA DATA WAREHOUSE DAOP 1 JAKARTA PT. KAI (PERSERO) Rakhmat Arianto; Chandra Bagus Sugiarto

IMPLEMENTASI METODE DETEKSI TEPI CANNY PADA OBJEK SEBAGAI MODEL KEAMANAN APLIKASI PADA SMARTPHONE ANDROID

Abdul Haris; Andi Prasetyo

ANALISA DATA DAN PERANCANGAN APLIKASI SERVICE PELANGGAN PT. JNE UNTUK PENINGKATAN KUALITAS LAYANAN

Dewi Arianti Wulandari; Sonny Syahrindra Putra

JARINGAN AD-HOC VEHICULAR (VANET) : TINJAUAN TENTANG ARSITEKTUR, KARAKTERISTIK, APLIKASI, DAN PROTOKOL MEDIUMACCESS CONTROL (MAC)

Rosida Nur Aziza

PERANCANGAN APLIKASI PENJADWALAN MATA KULIAH MENGGUNAKAN METODE CONSTRAINT PROGRAMMING Syam Gunawan

RANCANGAN TATA KELOLA PEREMAJAAN RUANG KELAS DIREKTORAT PEMBINAAN SEKOLAH DASAR

Ratna Mutu Manikam; Purwanto

PENGEMBANGAN AMORIK MENGGUNAKAN METODE GARIS SINGGUNG TERHADAP DUA LINGKARAN DAN PERSAMAAN KURVA BEZIER ORDE DUA.

Darma Rusjidi

OPTIMALISASI PENGAMBILAN KEPUTUSAN PENILAIAN KINERJA DOSEN PADA PERGURUAN TINGGI ISLAM XYZ MENGGUNAKAN AHP (ANALYTICAL HIERARCHY PROCESS)

Rahma Farah Ningrum

PENGAMANAN SMS PADA TELEPON SELULER BERBASIS ANDROID MENGGUNAKAN ALGORITMA TRIPLE DES Raka Yusuf; $M$. Rival Suheri

APLIKASI LATIHAN SOAL UJIAN TEORI SURAT IZIN MENGEMUDI BERBASIS WEB Harni Kusniyati; Raka Yusuf; Andri Setiawan

RANCANG BANGUN SIMULASI TERJADINYA LISTRIK DENGAN SUMBER DAYA SAMPAH BERBASIS MULTIMEDIA (STUDI KASUS : TPST BANTAR GEBANG)

Yasni Djamain; Ika Fitriyani Putri

\begin{tabular}{|c|c|c|c|c|c|c|}
\hline \multirow{2}{*}{ 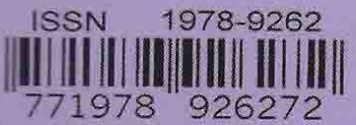 } & \multicolumn{6}{|c|}{ SEKOLAH TINGGI TEKNIK - PLN (STT-PLN) } \\
\hline & PETIR & VOL. 9 & NO. 1 & HAL. 1 - 87 & JAKARTA, MARET 2016 & ISSN $1978-9262$ \\
\hline
\end{tabular}




\title{
APLIKASI LATIHAN SOAL UJIAN TEORI SURAT IZIN MENGEMUDI BERBASIS WEB
}

\author{
Harni Kusniyati; Raka Yusuf; Andri Setiawan \\ Program Studi Sistem Informasi Fasilkom Universitas Mercu Buana \\ E-mail : harni246@gmail.com; raka@mercubuana.ac.id; contact@andry.my.id
}

\begin{abstract}
ABSTRAK
Semua pengemudi tentu akan merasa tenang apabila telah memiliki Surat Izin Mengemudi sebagai salah satu syarat mengendarai kendaraan bermotor. Dalam kenyataannya, masih ada masyarakat yang kesulitan mengerjakan ujian teori yang diselenggarakan oleh kepolisian. Diharapkan dengan aplikasi ini dapat dijadikan pembelajaran dan membantu menghadapi ujian teori, khusus untuk masyarakat yang ingin membuat Surat Izin Mengemudi. Aplikasi ini dibangun dengan menggunakan metode pengembangan perangkat lunak Waterfall dan menggunakan UML untuk dokumentasi, spesifikasi, dan pemodelan sistem. Dalam implementasinya, aplikasi ini dibuat dengan menggunakan PHP Framework (Codelgniter) dan User Interface Framework (Bootstrap) serta menggunakan database MySQL untuk menyimpan data soal-soal latihan. Pengguna aplikasi ini dilengkapi dengan fitur koreksi, jika diaktifkan, pengguna dapat mengoreksi jawaban setiap soal yang ditampilkan.
\end{abstract}

Kata Kunci: Surat Izin Mengemudi, Ujian Teori, Latihan Soal

\section{PENDAHULUAN}

\subsection{Latar Belakang}

Surat Izin Mengemudi (SIM) berfungsi sebagai bukti kompetensi (kemampuan) seseorang dalam mengemudi kendaraan bermotor dan juga sebagai registrasi data pengemudi kendaraan bermotor yang digunakan untuk mendukung penyelidikan, penyidikan dan identifikasi forensik kepolisian. Setiap orang wajib memiliki SIM untuk dapat mengemudikan kendaraan bermotor. Prosedur pembuatan SIM terbilang mudah dan praktis, salah satunya adalah mengikuti ujian teori. Namun, tidak sedikit calon pengemudi yang gagal dalam ujian teori ini dikarenakan tidak ada persiapan dengan latihan soal-soal ujian teori untuk mendapatkan SIM.

\subsection{Rumusan Masalah}

Berdasarkan latar belakang permasalahan di atas dapat dirumuskan menjadi beberapa masalah sebagai berikut:

1. Bagaimana merancang dan membangun sistem perangkat lunak berbasis web menghadapi ujian teori pembuatan Surat Izin Mengemudi?

2. Bagaimana menerapkan fitur pengecekan jawaban pada soal-soal yang ditampilkan?

\subsection{Batasan Masalah}

Berdasarkan rumusan masalah, maka batasan masalah dalam penelitian ini adalah sebagai berikut:

1. Rancang bangun aplikasi latihan soal ujian teori untuk mendapatkan Surat Izin Mengemudi hanya terbatas pada satu golongan, yaitu Golongan SIM A.

2. Halaman pengguna tidak memiliki fitur login. Pengguna dapat mengoreksi jawaban benar atau salah di setiap soal yang ditampilkan, serta menampilkan nilai persentase. Dimana nilai yang diperoleh tidak dimasukkan dalam database.

3. Halaman admin memiliki fitur login, penambahan, perubahan, dan penghapusan soal-soal latihan.

4. Soal-soal pada aplikasi ini berupa teks maupun gambar dan sistem menampilkan soal secara acak (random).

5. Aplikasi berbasis web ini hanya bisa berjalan di peramban internet (browser). Tampilan lebih sempurna jika dijalankan pada browser desktop, bukan browser mobile.

\subsection{Tujuan dan Manfaat}

Tujuan dari penelitian ini melakukan rancang bangun aplikasi latihan soal yang dilengkapi fitur pengecekan jawaban. Adapun manfaat dari penelitian ini untuk memudahkan seseorang atau calon pengemudi kendaraan bermotor dalam menghadapi ujian teori untuk mendapatkan Surat Izin Mengemudi dalam bentuk soal-soal latihan berbasis web.

\subsection{Metodologi Penelitian}

Dalam melakukan penelitian, penulis menggunakan metode rekayasa perangkat lunak model waterfall development. Waterfall development merupakan salah satu metode pengembangan perangkat lunak yang banyak digunakan.

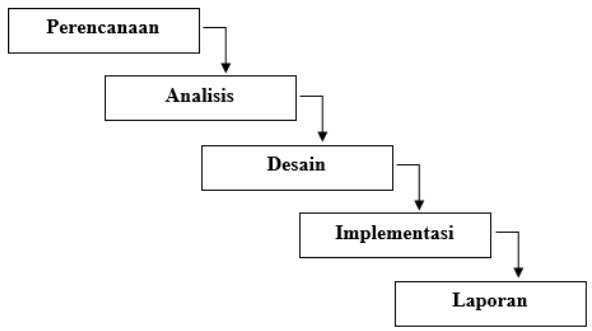

Gambar 1. Model Waterfall Development 
Adapun uraian dari masing-masing tahapan sistem adalah sebagai berikut:

1. Perencanaan

Merupakan tahapan untuk mengetahui kenapa sistem tersebut dibangun dan menjelaskan pengalokasian sumber daya untuk membangun sistem tersebut. Kegiatan yang dilakukan dalam tahapan ini adalah inisiasi proyek, analisa kelayakan dan manajemen proyek.

2. Analisis

Merupakan tahapan untuk mengetahui apa yang akan dilakukan oleh sistem, siapa yang menggunakannya, dimana dan kapan sistem tersebut digunakan. Dan dalam hal ini juga dianalisa kebutuhan sistem secara keseluruhan dan rinci.

3. Desain

Merupakan tahapan untuk mengetahui bagaimana sistem akan beroperasi, meliputi perangkat keras (hardware), perangkat lunak (software), basis data (database), program, antarmuka pengguna (user interface) yang dibutuhkan oleh sistem tersebut. Kegiatan yang dilakukan dalam tahapan ini adalah strategi desain, arsitektur sistem, spesifikasi basis data dan file, serta kode program.

4. Implementasi

Tahapan proses untuk mengeksekusi sistem secara nyata. Kegiatan yang dilakukan dalam tahapan ini adalah kostruksi, instalasi dan support.

5. Laporan

Dalam tahap ini penyusun melakukan dokumentasi untuk semua bahan,data modulmodul yang telah selesai dikerjakan dari tahap awal sampai dengan tahap akhir pengerjaan yang berhubungan dengan sistem yang dikerjakan dalam bentuk laporan tugas akhir.

\section{LANDASAN TEORI}

\subsection{Pengertian Website}

Web merupakan media informasi berbasis jaringan komputer yang dapat diakses di mana saja dengan biaya relative murah. Web merupakan bentuk implementasi dari bahasa pemrograman web (web programming). Sejarah perkembangan bahasa pemrograman web diawali dengan munculnya HTML (Hypertext Markup Language), yang kemudian dikembangkan dengan munculnya CSS (Cascading Style Sheet) yang bertujuan untuk memperindah tampilan website [9].

Informasi yang disajikan dalam halaman web menggunakan konsep multimedia, informasi dapat disajikan dengan menggunakan banyak media (teks, gambar, animasi, suara (audio), dan atau video. Dalam suatu halaman web, informasi akan dapat disajikan dalam kombinasi media teks, gambar, animasi, suara, atau video, semuanya dapat disajikan dalam satu halaman.

\subsubsection{Jenis-jenis Website}

Secara umum, situs web digolongkan menjadi

3 jenis yaitu sebagai berikut:

a. Website Statis

Website Statis adalah web yang mempunyai halaman tidak berubah. Artinya adalah untuk melakukan perubahan pada suatu halaman dilakukan secara manual dengan mengedit code yang menjadi struktur dari situs tersebut.

b. Website Dinamis

Website Dinamis merupakan website yang secara struktur diperuntukan untuk update sesering mungkin. Biasanya selain utama yang bisa diakses oleh user pada umumnya, juga disediakan halaman admin untuk mengedit konten.

c. Website Interaktif

Website Interaktif adalah web yang saat ini memang sedang booming. Salah satu contoh website interaktif adalah blog dan forum. Di website ini user bisa berinteraksi dan beradu argument mengenai apa yang menjadi pemikiran mereka.

\subsubsection{Aplikasi Web}

Aplikasi web adalah aplikasi yang disimpan dan dieksekusi di lingkungan web server. Setiap permintaan yang dilakukan oleh user melalui aplikasi klien (web browser) akan direspon oleh aplikasi web dan hasilnya akan dikembalikan lagi ke hadapan user [5].

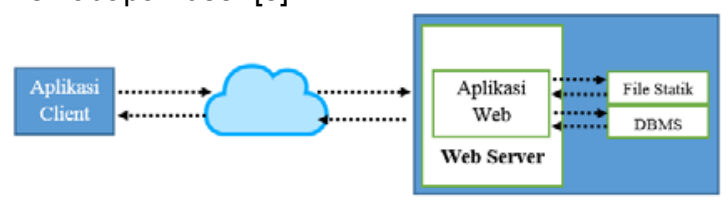

Gambar 2. Komunikasi Antara Web Browser dan Aplikasi Web

\subsection{Bahasa Pemrograman PHP}

PHP (Hypertext Preprocessor) merupakan bahasa pemrograman berbasis web yang memiliki kemampuan untuk memproses dan mengolah data secara dinamis. PHP dapat dikatakan sebagai sebuah server-side embedded script language, artinya semua sintaks dan perintah program akan sepenuhnya dijalankan oleh server, tetapi dapat disertakan pada halaman HTML biasa [9].

Pada prinsipnya, server akan bekerja apabila ada permintaan dari client. Dalam hal ini, client menggunakan kode-kode PHP akan mengirim permintaan ke server.

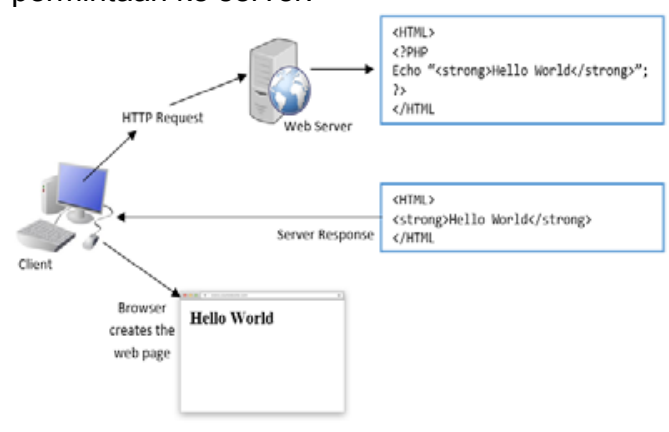

Gambar 3. Siklus PHP dalam Web Server 


\subsubsection{Statistik Penggunaan PHP}

Berdasarkan laporan Netcraft, pada Januari 2013 bahasa pemrograman PHP digunakan kurang lebih 244 juta oleh situs web dari jumlah sekitar 629 juta hasil survey Netcraft.

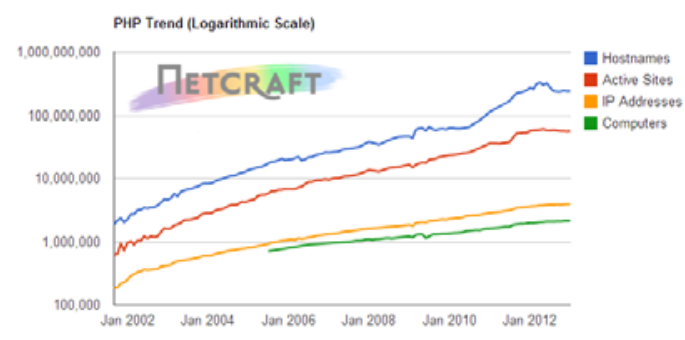

Gambar 4. Grafik Penggunaan PHP

Diagram di bawah ini menunjukkan persentase website yang menggunakan berbagai bahasa pemrograman server-side.

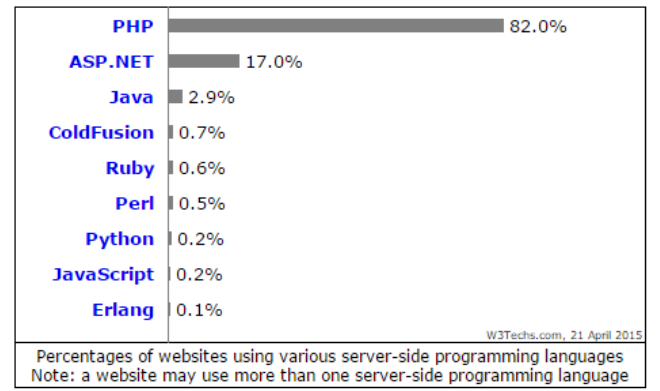

Gambar 5 Diagram Penggunaan PHP

\subsection{Basis Data}

Basis data atau Database adalah suatu aplikasi yang menyimpan sekumpulan data. Setiap database mempunyai API (Application Programming Interface) tertentu untuk membuat, mengakses, mengatur, mencari dan menyalin data yang ada di dalamnya [2].

MySQL merupakan suatu database. MySQL dapat juga dikatakan sebagai database yang sangat cocok bila dipadukan dengan PHP. Secara umum, database berfungsi sebagai tempat atau wadah untuk menyimpan, mengklasifikasikan data secara prefesional. MySQL bekerja menggunakan SQL Language (Structure Query Language).

\subsection{Kerangka Kerja (Framework)}

Kerangka Kerja atau Framework merupakan banyak kode yang disimpan dalam beberapa file yang terpisah, dan memudahkan dalam penggunaan kode yang digunakan secara berulang-ulang [2].

\subsubsection{PHP Framework (Codelgniter)}

Codelgniter adalah aplikasi close source yang berupa framework dengan model MVC (Model, View, Controller) untuk membangun website dinamis dengan menggunakan PHP. Codelgniter memudahkan developer untuk membuat aplikasi web dengan cepat dan mudah dibandingkan dengan membuatnya dari awal.

\subsubsection{User Interface Framework (Bootstrap)}

Bootstrap merupakan framework untuk membangun desain web secara responsif. Artinya, tampilan web yang dibuat oleh bootstrap akan menyesuaikan ukuran layar dari browser yang kita gunakan baik di desktop, tablet ataupun mobile device. Bootstrap dibangun dengan teknologi HTML dan CSS yang dapat membuat layout halaman website, tabel, tombol, form, navigasi, dan komponen lainnya dalam sebuah website hanya dengan memanggil fungsi CSS (class) dalam berkas HTML yang telah didefinisikan.

\subsection{Unified Modeling Language (UML)}

Unified Modeling Language merupakan salah satu alat bantu yang dapat digunakan dalam bahasa pemrograman berorientasi objek, saat ini UML sudah menjadi standar masa depan bagi industri pengembangan sistem/perangkat lunak yang akan berorientasi objek, sebab pada dasarnya UML telah digunakan oleh banyak perusahaan raksasa seperti IBM, Microsoft, dan sebagainya.

\subsubsection{Notasi Dasar UML}

Notasi UML merupakan sekumpulan bentuk khusus untuk menggambarkan berbagai diagram piranti lunak. Setiap bentuk memiliki makna tertentu, dan UML syntax mendefinisikan bagaimana bentuk-bentuk tersebut dapat dikombinasikan.

1. Actor

Actor adalah segala sesuatu yang berinteraksi langsung dengan sistem seperti orang, benda atau lainnya.

2. Class

Notasi utama dan yang paling mendasar pada diagram UML adalah notasi untuk mempresentasikan suatu class beserta dengan atribut dan operasinya.

3. Use Case

Sebuah use case merepresentasikan sebuah interaksi antara actor dengan sistem.

4. Activity Diagram

Activity diagram menggambarkan berbagai alur aktifitas dalam sebuah sistem yang sedang dirancang.

Tabel 1 Notasi Activity Diagram pada UML

\begin{tabular}{|l|l|l|}
\hline No. & Notasi & Keterangan \\
\hline 1 & & Titik awal. \\
\hline 2 & & $\begin{array}{l}\text { Menunjukan titik akhir dari } \\
\text { activity diagram. }\end{array}$ \\
\hline 3 & Final node & $\begin{array}{l}\text { Pilihan untuk mengambil } \\
\text { keputusan. } \\
\text { Mengindikasikan suatu } \\
\text { kondisi dimana ada } \\
\text { kemungkinan perbedaan } \\
\text { transisi. }\end{array}$ \\
\hline
\end{tabular}




\begin{tabular}{|l|l|l|}
\hline 4 & & $\begin{array}{l}\text { Menggambarkan sebuah } \\
\text { pekerjaan/aktivitas dalam } \\
\text { workflow. }\end{array}$ \\
\hline 5 & Action & $\begin{array}{l}\text { Menunjukan adanya } \\
\text { percabangan secara } \\
\text { paralel dari aktivitas. }\end{array}$ \\
\hline
\end{tabular}

5. Sequence Diagram

Sequence diagram menggambarkan interaksi antar objek di dalam dan di sekitar sistem (termasuk pengguna, display, dan sebagainya) berupa message yang digambarkan terhadap waktu.

Tabel 2. Notasi Sequence Diagram pada UML

\begin{tabular}{|c|c|c|}
\hline No. & Notasi & Keterangan \\
\hline 1 & Object lifeline & $\begin{array}{l}\text { Sebuah objek yang } \\
\text { berpartisipasi secara } \\
\text { berurutan dengan } \\
\text { mengirimkan atau menerima } \\
\text { pesan. }\end{array}$ \\
\hline 2 & Activation & $\begin{array}{l}\text { Menandakan ketika suatu } \\
\text { objek mengirim atau } \\
\text { menerima pesan. }\end{array}$ \\
\hline 3 & $\longrightarrow$ & $\begin{array}{l}\text { Menyatakan bahwa suatu } \\
\text { objek mengirimkan masukkan } \\
\text { ke objek lainnya. }\end{array}$ \\
\hline 4 & $\begin{array}{l}<-- \\
\text { Return } \\
\text { message }\end{array}$ & $\begin{array}{l}\text { Objek menghasilkan suatu } \\
\text { kembalian ke objek tertentu. }\end{array}$ \\
\hline
\end{tabular}

\section{ANALISIS DAN PERANCANGAN}

\subsection{Analisis}

Mengendarai kendaraan tidak sembarangan, ada aturan-aturan yang harus ditaati dan juga syarat-syarat tertentu yang harus dipenuhi sebelum berkendara di jalanan umum. Karena jalan umum adalah milik bersama maka wajib bagi semua pengendara mematuhi aturan-aturan yang telah ditetapkan. Tentu saja aturan dibuat ada tujuannya, misalnya untuk meminimalisir hal-hal buruk yang bisa terjadi sehingga akan tercipta keselamatan di jalan. Sebelum berkendara, salah satu syarat yang harus dimiliki oleh pengendara adalah Surat ljin Mengemudi (SIM).

Salah satu syarat untuk mendapatkan Surat Izin Mengemudi (SIM) di setiap golongan adalah lulus ujian atau tes teori yang diadakan oleh kepolisian. Ujian teori yang dilakukan menyangkut pengetahuan tentang berlalu-lintas, ketentuan umum tentang lalu-lintas hingga peraturan lalulintas lainnya.

\subsection{Pemodelan}

Pemodelan (modeling) adalah proses merancang sistem atau perangkat lunak sebelum pengkodean (coding). Bahasa pemodelan standar untuk sistem atau perangkat lunak adalah UML (Unified Modeling Language). UML digunakan untuk menggambarkan, mendeskripsikan, merancang, dan mendokumentasikan sistem perangkat lunak.

\subsubsection{Diagram Use Case}

Diagram Use Case menggambarkan fungsionalitas yang diharapkan dari sebuah sistem. Diagram use case merepresentasikan sebuah interaksi antara aktor dengan sistem. Aktor adalah sebuah entitas manusia atau mesin yang berinteraksi dengan sistem untuk melakukan pekerjaan tertentu.

\subsubsection{Deskripsi Use Case}

Setelah menentukan use case yang ada pada sistem, maka penjelasan masing-masing use case yang terdapat pada Diagram Use Case dapat dilihat pada tabel-tabel di bawah ini.

Tabel 3 Deskripsi Use Case Mengerjakan Soal

\begin{tabular}{|l|l|l|}
\hline Use Case & : Mengerjakan Soal & ID : 001 \\
\hline Aktor & : Pengguna \\
\hline & \\
Deskripsi : \\
1. Pengguna membuka halaman utama \\
2. Pengguna mengklik tombol mulai pada halaman \\
utama \\
3. Sistem akan menampilkan soal secara acak dan \\
tombol pilihan jawaban \\
4. Pengguna mengerjakan soal dengan memilih \\
5. Penaban \\
soal selanjutnya
\end{tabular}

Tabel 4 Deskripsi Use Case Mengoreksi Jawaban

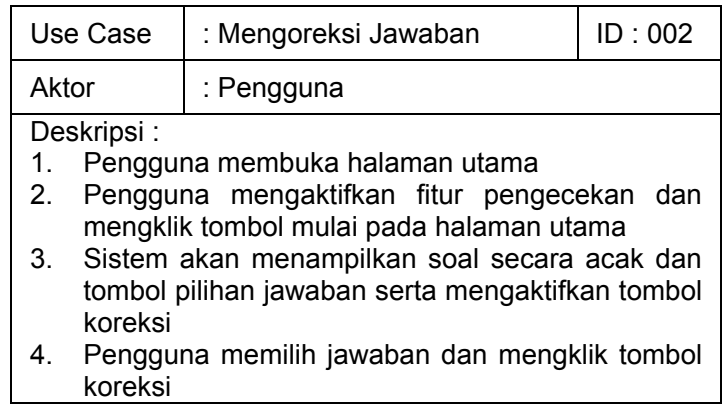

Tabel 5 Deskripsi Use Case Melihat Hasil

\begin{tabular}{|l|l|l|}
\hline Use Case & : Melihat Hasil & ID : 003 \\
\hline Aktor & : Pengguna \\
\hline Deskripsi : \\
1. Pengguna membuka halaman utama \\
2. Pengguna mengklik tombol mulai pada halaman \\
utama \\
3. Sistem akan menampilkan soal secara acak dan \\
tombol pilihan jawaban \\
4. Pengguna mengerjakan soal dan mengklik tombol \\
lanjut untuk beralih ke soal selanjutnya \\
5. Setelah mengerjakan soal nomor 25, pengguna \\
mengklik tombol lanjut dan sistem akan \\
menampilkan hasil
\end{tabular}


Tabel 6 Deskripsi Use Case Menambah Soal

\begin{tabular}{|l|l|l|}
\hline Use Case & : Menambah Soal & ID : 004 \\
\hline Aktor & : Administrator \\
\hline Deskripsi : \\
1. Administrator melakukan login ke dalam sistem \\
melalui halaman login administrator. \\
2. Sistem menampilkan halaman indeks soal yang \\
berisi daftar soal-soal \\
3. Administrator mengklik tombol tambah soal \\
4. Sistem menampilkan form menambah soal \\
5. Administrator mengisi form dan mengklik tombol \\
simpan \\
\hline
\end{tabular}

Tabel 7 Deskripsi Use Case Mengubah Soal

\begin{tabular}{|c|c|}
\hline Use Case & : Mengubah Soal \\
\hline Aktor & : Administrator \\
\hline \multicolumn{2}{|c|}{$\begin{array}{l}\text { Deskripsi : } \\
\text { 1. Administrator melakukan login ke dalam sistem } \\
\text { melalui halaman login administrator. } \\
\text { 2. Sistem menampilkan halaman indeks soal yang } \\
\text { berisi daftar soal-soal } \\
\text { 3. Administrator mengklik tombol ubah pada daftar } \\
\text { soal yang dipilih } \\
\text { 4. Sistem menampilkan halaman mengubah soal } \\
\text { 5. Administrator mengubah soal dan mengklik tombol } \\
\text { simpan }\end{array}$} \\
\hline
\end{tabular}

Tabel 8 Deskripsi Use Case Menghapus Soal

\begin{tabular}{|c|c|c|}
\hline Use Case & : Menghapus Soal & ID : 006 \\
\hline Aktor & \multicolumn{2}{|l|}{ : Administrator } \\
\hline \multicolumn{3}{|c|}{$\begin{array}{l}\text { Deskripsi : } \\
\text { 1. Administrator melakukan login ke dalam sistem } \\
\text { melalui halaman login administrator. } \\
\text { 2. Sistem menampilkan halaman indeks soal yang } \\
\text { berisi daftar soal-soal } \\
\text { 3. Administrator mengklik tombol hapus pada daftar } \\
\text { soal yang dipilih }\end{array}$} \\
\hline
\end{tabular}

\subsubsection{Activity Diagram}

Activity Diagram memodelkan alur kerja (workflow) sebuah urutan aktivitas pada suatu proses. Diagram ini sangat mirip dengan flowchart karena memodelkan prosedur logika, proses bisnis dan alur kerja. Dalam hal ini, activity diagram akan menggambarkan urutan aktifitas yang terjadi pada proses dalam aplikasi soal latihan ujian teori SIM. Berikut masing-masing activity diagram dari setiap proses:

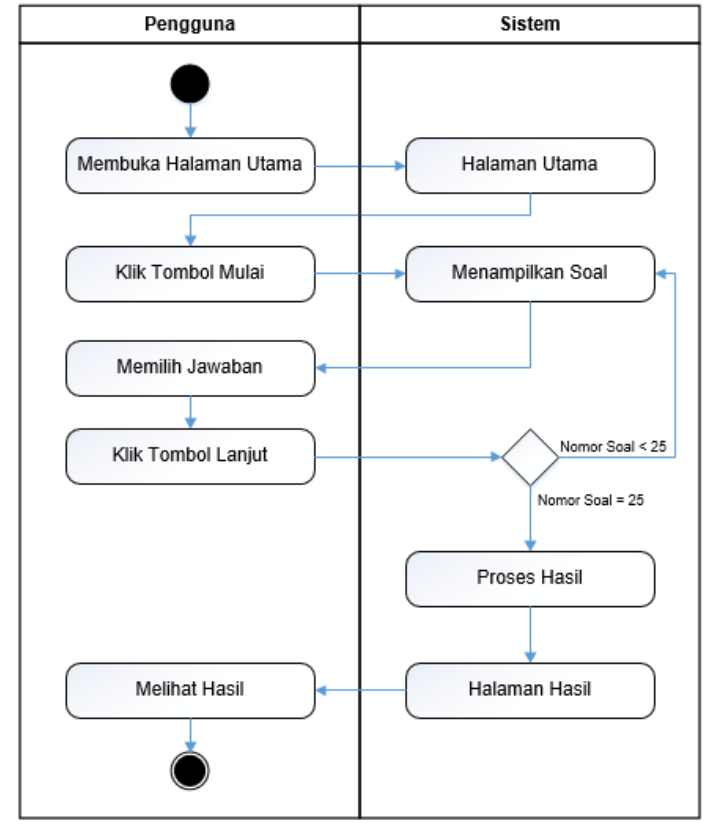

Gambar 6 Activity Diagram Mengerjakan Soal dan Melihat Hasil

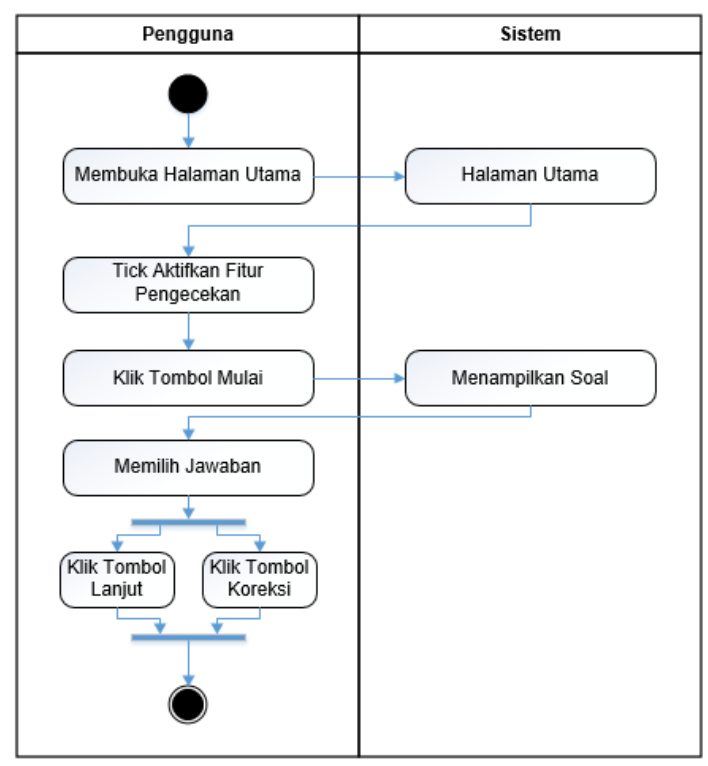

Gambar 7 Activity Diagram Mengoreksi Jawaban 


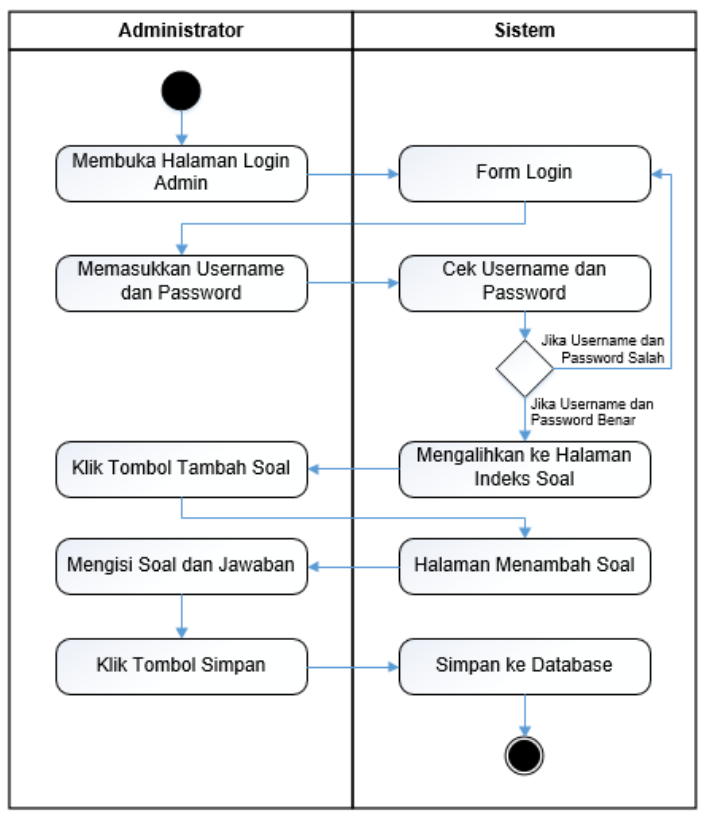

Gambar 8 Activity Diagram Menambah Soal

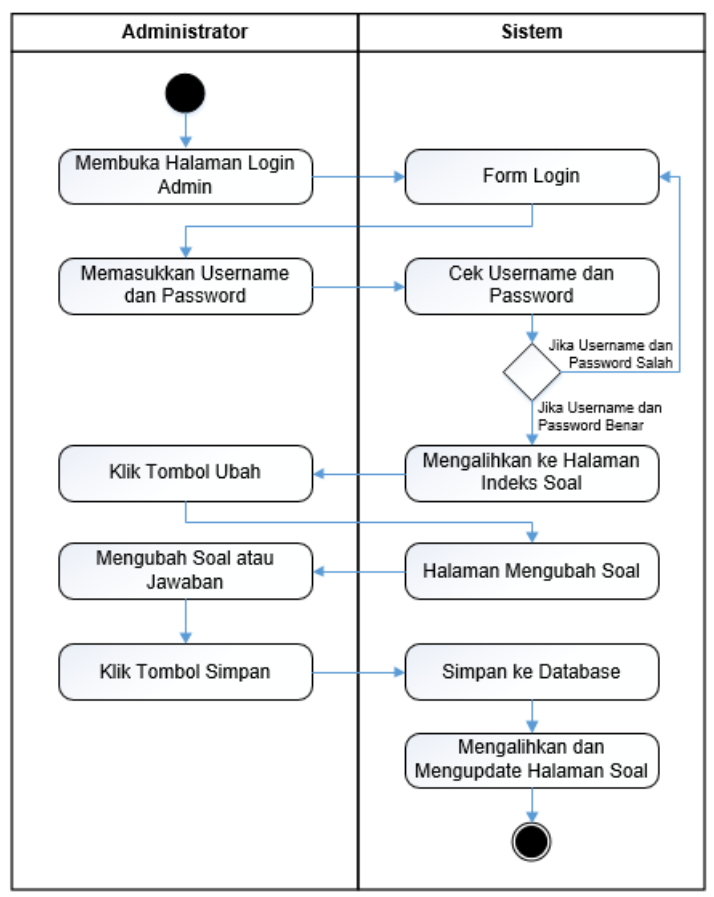

Gambar 9 Activity Diagram Mengubah Soal

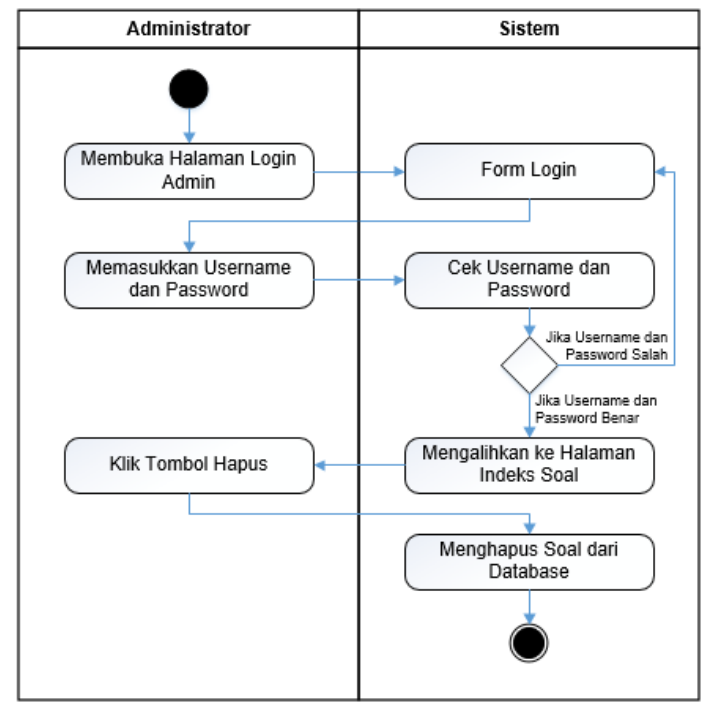

Gambar 10 Activity Diagram Menghapus Soal

\subsubsection{Sequence Diagram}

Sequence Diagram menggambarkan interaksi antar objek di dalam dan disekitar sistem berupa message yang digambarkan terhadap waktu. Diagram ini secara khusus berasosiasi dengan diagram use case dan memperlihatkan tahap demi tahap apa yang seharusnya terjadi untuk menghasilkan sesuatu di dalam use case.

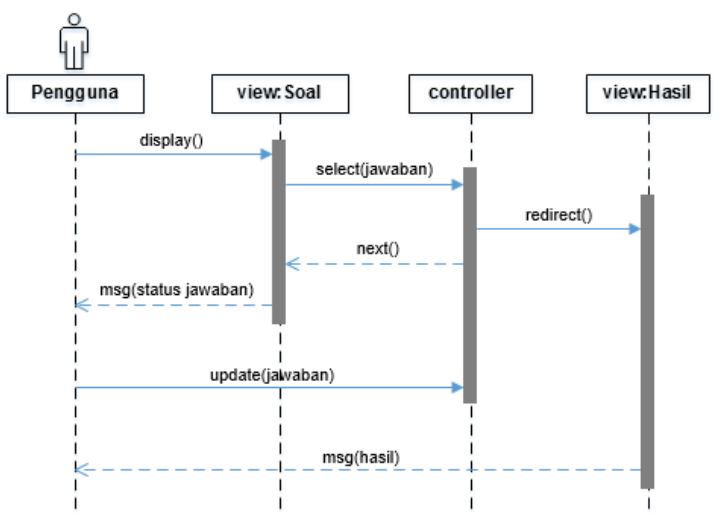

Gambar 11 Sequence Diagram Pengguna Mengerjakan, Mengoreksi dan Melihat Hasil

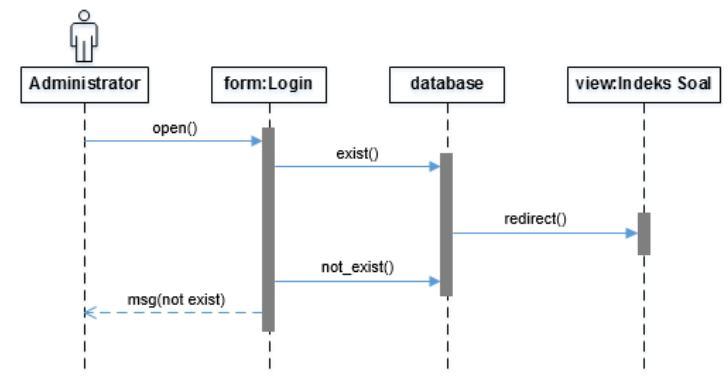

Gambar 12 Sequence Diagram Login 


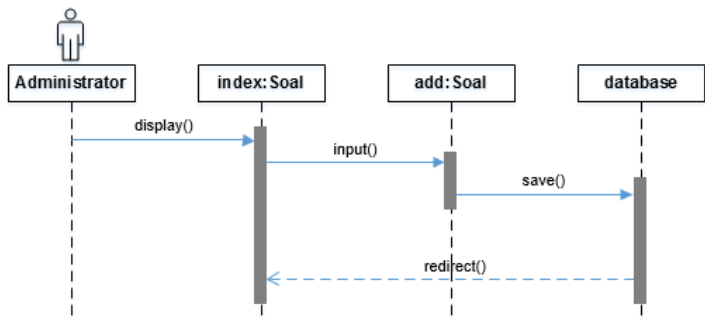

Gambar 13 Sequence Diagram Menambah Soal

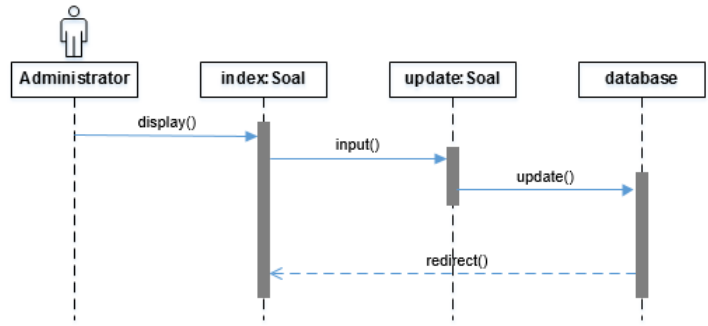

Gambar 14 Sequence Diagram Mengubah Soal

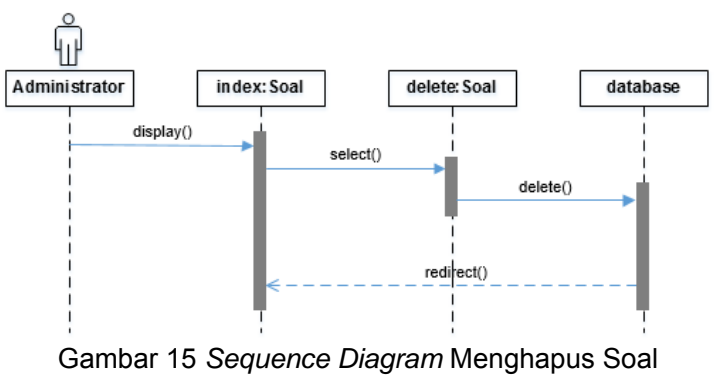

\subsubsection{Class Diagram}

Class diagram menggambarkan struktur sistem dari segi pendefinisian kelas-kelas yang akan dibuat untuk membangun sistem. Pada umumnya, class diagram mempresentasikan hubungan (relationship) antar kelas. Dalam kasus ini tidak ditemukan adanya hubungan relasi antar kelas.
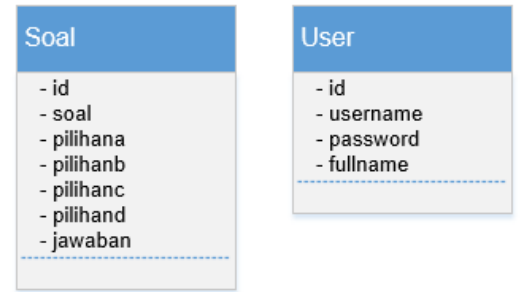

Gambar 16 Class Diagram Aplikasi Latihan Soal Ujian Teori

\subsection{Struktur Tabel Basis Data}

Struktur Tabel merupakan penjabaran dan penjelasan dari suatu database. Dalam struktur Tabel dijelaskan fungsi dari masing-masing Tabel hingga fungsi masing-masing field yang ada di dalam Tabel.

\subsubsection{Tabel soal}

Nama Tabel : soal

Primary Key : id

Foreign Key : :-

Fungsi : Untuk menyimpan data soal
Tabel 9 Struktur Database Tabel Soal

\begin{tabular}{|l|l|l|l|}
\hline No & Field & $\begin{array}{l}\text { Tipe } \\
\text { Data }\end{array}$ & Keterangan \\
\hline 1 & id & integer & Kode identitas soal \\
\hline 2 & soal & text & Materi soal latihan \\
\hline 3 & pilihana & text & Pilihan jawaban dari soal \\
\hline 4 & pilihanb & text & Pilihan jawaban dari soal \\
\hline 5 & pilihanc & text & Pilihan jawaban dari soal \\
\hline 6 & pilihand & text & Pilihan jawaban dari soal \\
\hline 7 & jawaban & char & Jawaban yang tepat dari soal \\
\hline
\end{tabular}

3.3.2. Tabel user

Nama Tabel : user

Primary Key : id

Foreign Key : :

Fungsi : Untuk menyimpan data user

Tabel 10 Struktur Database Tabel User

\begin{tabular}{|l|l|l|l|}
\hline No & Field & $\begin{array}{l}\text { Tipe } \\
\text { Data }\end{array}$ & Keterangan \\
\hline 1 & id & integer & Kode identitas user \\
\hline 2 & username & varchar & Nama login user \\
\hline 3 & password & varchar & Password user \\
\hline 4 & fullname & varchar & Nama lengkap user \\
\hline
\end{tabular}

\subsection{Perancangan Antar Muka}

Setelah disusun dan dirancang struktur basis data, berikutnya adalah rancangan antar muka (user-interface) dari sistem yang dibangun. Dengan adanya rancangan antar muka ini, akan segera diketahui gambaran mendetail dari aplikasi latihan soal ujian teori SIM. Perancangan antar muka ini juga akan mewakili keadaan sebenarnya dari aplikasi yang akan dibangun.

\section{IMPLEMENTASI DAN PENGUJIAN}

4.1. Implementasi Sistem

Implementasi merupakan kelanjutan dari kegiatan perancangan sistem dan dapat dipandang sebagai usaha untuk mewujudkan sistem yang dirancang. Langkah-langkah dari proses implementasi adalah urutan dari kegiatan awal sampai kegiatan akhir yang harus dilakukan dalam mewujudkan sistem yang dirancang. Hasil dari tahapan implementasi ini adalah suatu sistem pengolahan data yang sudah dapat berjalan dengan baik.

\subsubsection{Spesifikasi Kebutuhan Sistem}

Spesifikasi kebutuhan sistem pada area kerja dan pengujian terbagi menjadi 2 (dua) yaitu perangkat keras dan perangkat lunak yang dapat dilihat pada keterangan di bawah ini:

1. Perangkat Keras

- Prosesor Intel® Core ${ }^{\mathrm{TM}}$ i5-4210M (3M Cache, $2.6 \mathrm{GHz}$ )

- Memori 4GB, PC3-12800 1600MHz DDR3L

- Hardisk 500GB 7200 RPM

- VGA Intel HD Graphics 4600

2. Perangkat Lunak

- Sistem Operasi, Windows 8.1 64-bit 
- Peramban Internet, Google Chrome 44.0.2403.125

- XAMPP Web Server v5.6.8

- Apache 2.4.12 (http server)

- $\quad$ MySQL 5.6.24

- PHP 5.6.8

- $\quad$ phpMyAdmin 4.4.3

- Framework Codelgniter 3.0.0 dan Bootstrap 3.3.5

- Text Editor CKEditor 4.5.1

\subsubsection{Pembuatan Database}

Pada tahap pertama dalam membangun aplikasi ini adalah pembuatan databasenya terlebih dahulu.

Q6. Create database (e)

simonline $\quad$ Collation $\quad$ Create

Gambar 17 Membuat Database dengan phpMyAdmin

\subsubsection{Antar Muka Sistem (Interface)}

Berikut ini adalah implementasi antar muka dari aplikasi yang dibuat:

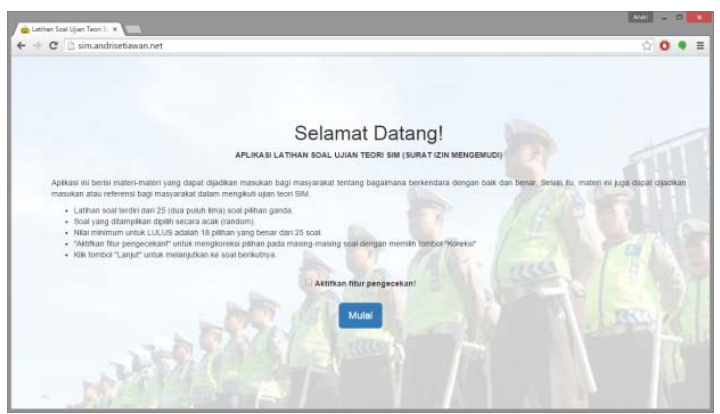

Gambar 18 Implementasi Halaman Utama Pengguna

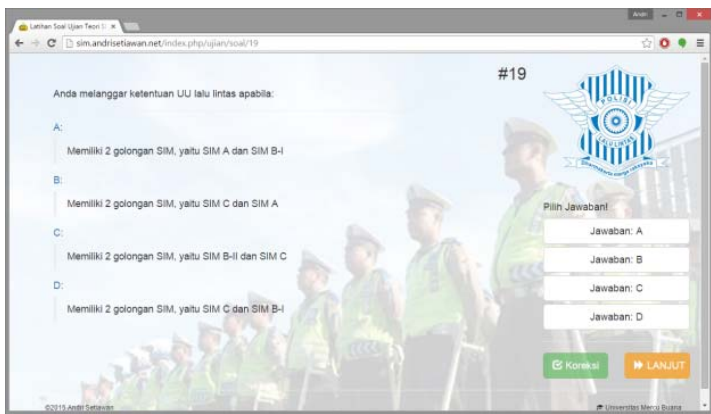

Gambar 19 Implementasi Halaman Soal Llatihan

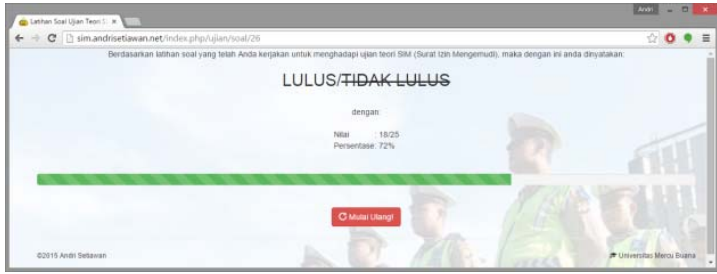

Gambar 20 Implementasi Halaman Hasil

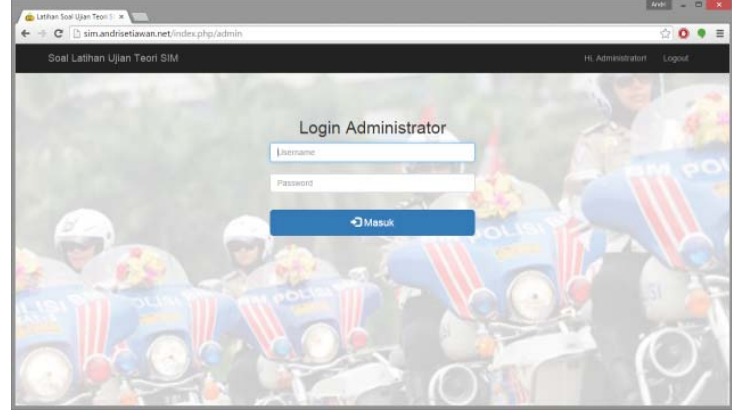

Gambar 21 Implementasi Halaman Login Admin

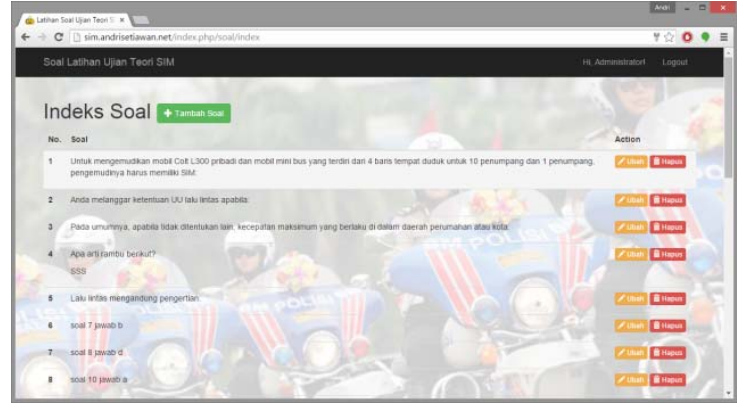

Gambar 22 Implementasi Halaman Indeks Soal

\subsection{Pengujian Sistem}

Pengujian bermaksud untuk mengetahui perangkat lunak yang dibuat sudah memenuhi kriteria yang sesuai dengan tujuan perancangan perangkat lunak tersebut.

\subsubsection{Pengujian Antar Muka Pengguna}

Tabel 11 Daftar Pengujian pada Antar Muka Pengguna

\begin{tabular}{|c|c|c|c|}
\hline $\begin{array}{l}\text { Case } \\
\text { ID }\end{array}$ & $\begin{array}{l}\text { Data } \\
\text { Masukan }\end{array}$ & Pengamatan & $\begin{array}{l}\text { Kesimpula } \\
\mathbf{n}\end{array}$ \\
\hline 1 & $\begin{array}{l}\text { Klik tombol } \\
\text { "Mulai". }\end{array}$ & $\begin{array}{l}\text { Dapat } \\
\text { menampilkan } \\
\text { soal latihan. }\end{array}$ & $\begin{array}{l}\text { [v] Diterima } \\
\text { [ ] Ditolak }\end{array}$ \\
\hline 2 & $\begin{array}{l}\text { Check pada } \\
\text { "Aktifkan fitur } \\
\text { pengecekan!" }\end{array}$ & $\begin{array}{l}\text { Dapat } \\
\text { menampilkan } \\
\text { soal latihan } \\
\text { dan tombol } \\
\text { "Koreksi" } \\
\text { dapat } \\
\text { digunakan }\end{array}$ & $\begin{array}{l}\text { [v] Diterima } \\
\text { [ ] Ditolak }\end{array}$ \\
\hline 3 & $\begin{array}{l}\text { Klik tombol } \\
\text { "Lanjut" tanpa } \\
\text { memillih } \\
\text { jawaban. }\end{array}$ & $\begin{array}{l}\text { Dapat } \\
\text { menampilkan } \\
\text { pesan } \\
\text { kesalahan } \\
\text { "Silakan pilih } \\
\text { jawaban } \\
\text { untuk } \\
\text { melanjutkan!" }\end{array}$ & $\begin{array}{l}\text { [v] Diterima } \\
\text { [ ] Ditolak }\end{array}$ \\
\hline 4 & $\begin{array}{l}\text { Memilih } \\
\text { jawaban dan } \\
\text { klik tombol } \\
\text { "Lanjut". }\end{array}$ & $\begin{array}{l}\text { Dapat } \\
\text { menampilkan } \\
\text { soal } \\
\text { selanjutnya. }\end{array}$ & $\begin{array}{l}\text { [v] Diterima } \\
\text { [ ] Ditolak }\end{array}$ \\
\hline 5 & $\begin{array}{l}\text { Klik tombol } \\
\text { "Koreksi" } \\
\text { tanpa memilih } \\
\text { jawaban }\end{array}$ & $\begin{array}{l}\text { Dapat } \\
\text { menampilkan } \\
\text { pesan } \\
\text { kesalahan }\end{array}$ & $\begin{array}{l}\text { [v] Diterima } \\
\text { [ ] Ditolak }\end{array}$ \\
\hline
\end{tabular}




\begin{tabular}{|c|c|c|c|}
\hline & & $\begin{array}{l}\text { "Anda belum } \\
\text { memilih } \\
\text { jawaban!" }\end{array}$ & \\
\hline 6 & $\begin{array}{l}\text { Klik tombol } \\
\text { "Koreksi" } \\
\text { dengan } \\
\text { memilih } \\
\text { jawaban yang } \\
\text { salah. }\end{array}$ & $\begin{array}{l}\text { Dapat } \\
\text { menampilkan } \\
\text { pesan } \\
\text { "Jawaban } \\
\text { SALAH" }\end{array}$ & $\begin{array}{l}\text { [v] Diterima } \\
\text { [ ] Ditolak }\end{array}$ \\
\hline 7 & $\begin{array}{l}\text { Klik tombol } \\
\text { "Koreksi" } \\
\text { dengan } \\
\text { memilih } \\
\text { jawaban yang } \\
\text { benar. }\end{array}$ & $\begin{array}{l}\text { Dapat } \\
\text { menampilkan } \\
\text { pesan } \\
\text { "Jawaban } \\
\text { BENAR" }\end{array}$ & $\begin{array}{l}\text { [v] Diterima } \\
\text { [ ] Ditolak }\end{array}$ \\
\hline 8 & $\begin{array}{l}\text { Klik tombol } \\
\text { "Lanjut" pada } \\
\text { soal nomor } \\
25 .\end{array}$ & $\begin{array}{l}\text { Dapat } \\
\text { menampilkan } \\
\text { hasil. }\end{array}$ & $\begin{array}{l}\text { [v] Diterima } \\
\text { [ ] Ditolak }\end{array}$ \\
\hline 9 & $\begin{array}{l}\text { Klik tombol } \\
\text { "Mulai ulang" } \\
\text { pada halaman } \\
\text { hasil }\end{array}$ & $\begin{array}{l}\text { Dapat } \\
\text { kembali ke } \\
\text { halaman } \\
\text { utama } \\
\text { pengguna }\end{array}$ & $\begin{array}{l}\text { [v] Diterima } \\
\text { [ ] Ditolak }\end{array}$ \\
\hline
\end{tabular}

\subsubsection{Pengujian Antar Muka Administrator}

Tabel 12 Daftar Pengujian pada Antar Muka Administrator

\begin{tabular}{|c|c|c|c|}
\hline $\begin{array}{l}\text { Case } \\
\text { ID }\end{array}$ & $\begin{array}{l}\text { Data } \\
\text { Masukan }\end{array}$ & Pengamatan & Kesimpulan \\
\hline 10 & $\begin{array}{l}\text { Klik tombol } \\
\text { "Masuk" tanpa } \\
\text { memasukkan } \\
\text { username dan } \\
\text { password }\end{array}$ & $\begin{array}{l}\text { Dapat } \\
\text { menampilkan } \\
\text { pesan } \\
\text { kesalahan } \\
\text { "Username } \\
\text { dan Password } \\
\text { Salah!" pada } \\
\text { halaman login } \\
\text { administrator }\end{array}$ & $\begin{array}{l}\text { [v] Diterima } \\
\text { [ ] Ditolak }\end{array}$ \\
\hline 11 & $\begin{array}{l}\text { Memasukkan } \\
\text { username dan } \\
\text { password } \\
\text { yang salah }\end{array}$ & $\begin{array}{l}\text { Dapat } \\
\text { menampilkan } \\
\text { pesan } \\
\text { kesalahan } \\
\text { "Username } \\
\text { dan Password } \\
\text { Salah!" pada } \\
\text { halaman login } \\
\text { administrator }\end{array}$ & $\begin{array}{l}\text { [v] Diterima } \\
\text { [ ] Ditolak }\end{array}$ \\
\hline 12 & $\begin{array}{l}\text { Memasukkan } \\
\text { username dan } \\
\text { password. Klik } \\
\text { tombol } \\
\text { "Masuk" } \\
\text { Username: } \\
\text { admin } \\
\text { Password: } \\
\text { AdminUMB13 }\end{array}$ & $\begin{array}{l}\text { Login sukses, } \\
\text { dapat } \\
\text { menampilkan } \\
\text { halaman } \\
\text { indeks soal }\end{array}$ & $\begin{array}{l}\text { [v] Diterima } \\
\text { [ ] Ditolak }\end{array}$ \\
\hline 13 & $\begin{array}{l}\text { Klik tombol } \\
\text { "Tambah Soal" } \\
\text { pada halaman } \\
\text { Indeks Soal }\end{array}$ & $\begin{array}{l}\text { Dapat } \\
\text { menampilkan } \\
\text { halaman } \\
\text { menambah } \\
\text { soal }\end{array}$ & $\begin{array}{l}\text { [v] Diterima } \\
\text { [ ] Ditolak }\end{array}$ \\
\hline 14 & $\begin{array}{l}\text { Klik tombol } \\
\text { "Simpan" pada } \\
\text { halaman } \\
\text { tambah soal }\end{array}$ & $\begin{array}{l}\text { Dapat } \\
\text { kembali ke } \\
\text { halaman } \\
\text { Indeks Soal } \\
\text { dan soal } \\
\end{array}$ & $\begin{array}{l}\text { [v] Diterima } \\
\text { [ ] Ditolak }\end{array}$ \\
\hline
\end{tabular}

\begin{tabular}{|c|c|c|c|}
\hline & & $\begin{array}{l}\text { berhasil } \\
\text { ditambahkan. }\end{array}$ & \\
\hline 15 & $\begin{array}{l}\text { Klik tombol } \\
\text { "Batal" pada } \\
\text { halaman } \\
\text { tambah soal }\end{array}$ & $\begin{array}{l}\text { Dapat } \\
\text { kembali ke } \\
\text { halaman } \\
\text { Indeks Soal. }\end{array}$ & $\begin{array}{l}\text { [v] Diterima } \\
\text { [ ] Ditolak }\end{array}$ \\
\hline 16 & $\begin{array}{l}\text { Klik tombol } \\
\text { "Ubah" pada } \\
\text { halaman } \\
\text { Indeks Soal }\end{array}$ & $\begin{array}{l}\text { Dapat } \\
\text { menampilkan } \\
\text { halaman ubah } \\
\text { soal. }\end{array}$ & $\begin{array}{l}\text { [v] Diterima } \\
\text { [ ] Ditolak }\end{array}$ \\
\hline 17 & $\begin{array}{l}\text { Klik tombol } \\
\text { "Simpan" pada } \\
\text { halaman ubah } \\
\text { soal }\end{array}$ & $\begin{array}{l}\text { Dapat } \\
\text { kembali ke } \\
\text { halaman } \\
\text { Indeks Soal } \\
\text { dan soal } \\
\text { berhasil } \\
\text { diubah. }\end{array}$ & $\begin{array}{l}\text { [v] Diterima } \\
\text { [ ] Ditolak }\end{array}$ \\
\hline 18 & $\begin{array}{l}\text { Klik tombol } \\
\text { "Batal" pada } \\
\text { halaman ubah } \\
\text { soal }\end{array}$ & $\begin{array}{l}\text { Dapat } \\
\text { kembali ke } \\
\text { halaman } \\
\text { Indeks Soal. }\end{array}$ & $\begin{array}{l}\text { [v] Diterima } \\
\text { [ ] Ditolak }\end{array}$ \\
\hline 19 & $\begin{array}{l}\text { Klik tombol } \\
\text { "Hapus" pada } \\
\text { halaman } \\
\text { Indeks Soal }\end{array}$ & $\begin{array}{l}\text { Soal yang } \\
\text { dipilih dapat } \\
\text { terhapus dari } \\
\text { halaman } \\
\text { Indeks Soal }\end{array}$ & $\begin{array}{l}\text { [v] Diterima } \\
\text { [ ] Ditolak }\end{array}$ \\
\hline
\end{tabular}

\section{KESIMPULAN DAN SARAN}

\subsection{Kesimpulan}

Dari uraian diatas, dapat diambil kesimpulan sebagai berikut:

1. Aplikasi latihan soal ujian teori Surat Izin Mengemudi berjalan dengan baik pada perambah internet (browser). Aplikasi ini dirancang dan dibangun menggunakan bahasa pemrograman PHP.

2. Pengguna dapat mengoreksi jawaban pada setiap soal yang ditampilkan secara acak oleh sistem dengan mengaktifkan fitur pengecekan jawaban di halaman utama pengguna.

\subsection{Saran}

Berikut ini adalah saran untuk pengembangan selanjutnya:

1. Penambahan kategori golongan Surat Izin Mengemudi, sehingga lebih tepat sasaran kepada pengguna yang ingin memahami soal-soal ujian teori dengan golongan SIM tertentu.

2. Tampilan dibuat lebih menarik dan interaktif. Misalnya penggunaan media suara (sound) pada saat pengguna memilih jawaban dan koreksi jawaban.

3. Aplikasi dapat dijalankan pada perangkat mobile (mobile devices). Meskipun aplikasi ini bisa diakses melalui mobile browser, akan lebih sempurna jika dibuatkan aplikasi berbasis mobile sehingga pengguna bisa mempelajari kapanpun dan dimanapun. 


\section{DAFTAR PUSTAKA}

[1] Alatas, Husein. 2013. Responsive Web Design dengan PHP dan Bootstrap. Yogyakarta: Lokomedia

[2] Jubilee Enterprise. 2015. Membuat Website PHP dengan Codelgniter. Jakarta: Elex Media Komputindo

[3] Lassoff, Mark. 2014. PHP and MySQL for Beginners. Connecticut

USA: LearnToProgram, Incorporated

[4] Pratama, Antonius Nugraha Widhi. 2010. Codelgniter: Cara Mudah Membangun Aplikasi PHP. Jakarta: Media Kita
[5] Raharjo, Budi, Imam Heryanto, dan E. Rosdiana K. 2014. Modul Pemrograman WEB (HTML, PHP, \& MySQL). Bandung: Penerbit Modula

[6] Sianipar, R.H. 2015. Membangun Web PHP dan MySQL. Bandung: Informatika Bandung

[7] Sidik, Betha. 2012. Framework Codelgniter. Bandung: Informatika Bandung

[8] Siswosoediro, Henry S. 2009. Buku Pintar Mengurus Surat \& Dokumen Kendaraan Bermotor. Jakarta: Visimedia

Wahana Komputer. 2009. ShortCourse Series: PHP Programming. Yogyakarta: Andi Publisher 